\title{
THE INFLUENCE OF INSTAGRAM DA'WAH ACCOUNT ON RELIGIOUS BEHAVIOR
}

\author{
Andini Nur Bahri \\ Islamic State University of North Sumatera \\ andininurbahri@uinsu.ac.id
}

\begin{abstract}
Instagram is a popular social media recently and most of its users are young people including students. Students are interested in using Instagram because it has interesting features such as photos and videos that can add to their insight, this also includes Islamic teachings. Many students become followers of the da'wah accounts that th ey access every day. This study aims to determine the influence of da'wah Instagram accounts on religious behavior among students of Islamic Communication and Broadcasting at the Islamic State University of North Sumatra. The research method used is a quantitative method. The result shows that there is no significant effect of the da'wah Instagram accounts on religious behavior.
\end{abstract}

Keywords: Instagram, Da'wah, Religious Behavior

\section{Introduction}

Communication is an important indicator for a scholar or preacher to succeed in his preaching. Therefore, the preacher should understand how da'wah communication can take place effectively. Da'wah communication is the process of delivering information or messages from a person or group of people to someone or a group of other people originating from the Quran and hadith using symbols both verbally and nonverbally with the aim of changing the attitudes, opinions or behavior of others who are more both according to Islamic teachings, either directly orally or indirectly through the media ${ }^{1}$.

In the era of globalization, Islamic religious leaders and others have started to use or take advantage of the media, be it mass media such as radio, television or social media such as Facebook, Twitter, Instagram, YouTube, and others ${ }^{2}$. One of the motivating factors for switching to new technologies is the high number of social media users. The most popular social media right

\footnotetext{
${ }^{1}$ Abdullah. (2007). E dakwah: berdakwah melalui internet. Al-Hikmah. Jurnal Ilmu Dakwah Dan Pengembangan Masyarakat, Edisi 02. P. 16-17

${ }^{2}$ Muchtar, N., \& Ritchey, J. A. (2014). Preaching, Community, and Convergence: Use of Old and New Media by Profressive Indonesian Islamic Leaders. The International Communication Gazette, P. 361
} 
now is Instagram along with the increasing number of users. One of the other advantages of Instagram is that the photos can be shared on other social media such as Facebook and Twitter, sothat these photos are not only seen by people who have Instagram ${ }^{3}$

In their study, Lup, Trub, and Rosenthal (2015) found that Instagram posts tend to be positively biased, as users engage in positive forms of self-presentation and select positive aspectsof their lives to display. While the literature remains sparse, Lup et al. (2015) posit that Instagramposts are generally more positively biased than Facebook posts. This is likely the result of photo editing and enhancing features that create a culture of polishing and perfecting among users. The current literature regarding Instagram use, while sparse, provides a conceptual basis for understanding how image-based social media has the potential to impact users' levels of well-beingand self-esteem ${ }^{4}$.

The number of Instagram users has reached 700 million, with an increase of 100 millionusers within 4 months with the most users being young people. Lately, many young people use Instagram both to preach and access da'wah content. This is evidenced by the number of da'wah accounts on Instagram that contain Islamic da'wah content where the followers are young people. These contents include material on aqidah, morals, fiqh, monotheism, Islamic politics and so on. When someone accesses da'wah on Instagram by reading, seeing and listening to posts from the da'wah account, it can be said that communication activities have occurred between the information giver, and the recipient of the information. This will certainly have a response effect and influence on the recipient of the information.

University students are one of the targets of Da'wah on Instagram because students are quite active users on Instagram. Students have a very high curiosity, in this case, students begin tothink highly of their religious teachings. To fulfill their curiosity, many students are looking for information about their religion. One way of seeking religious knowledge is through social media,like Instagram.

Based on several previous studies, one group of students who actively use Instagram

\footnotetext{
${ }^{3}$ Rangga Aditya, "Pengaruh Media Sosial Instagram Terhadap Minat Fotografi Pada Komunitas Fotografi Pekanbaru" Jom FISIP Volume 2 No. 2 (2015) P.3

${ }^{4}$ Lup, K., Trub, L., \& Rosenthal, L. (2015). Instagram \#instasad? Exploring associations among Instagram use, depressive symptoms, negative social comparison, and strangers followed. Cyberpsychology, Behavior, andSocial Networking, 18, 247
} 
to obtain Islamic da'wah information are students in various universities. Currently most students have smartphones based on Android and have accounts on Instagram.

That matter can be seen because every day students are allowed to bring cellphones to campus. With this phenomenon, it is necessary to have research related to how the program affectsthe religious behavior of Islamic Communication and Broadcasting students of UIN North Sumatra. This is because students majoring in Communication are considered to be more familiarwith social media.

\section{Literature Review}

\section{Instagram as Da'wah}

\section{Media}

Da'wah media is a tool that mediates the delivery of messages to Da'wah objects 5 . Da'wahmedia is an additional element in Da'wah activities. As a media that is trending, it is used to convey Da'wah messages, it will invite many Dai to contribute to da'wah through Instagram.

Instagram is one of the social networking media that can be used as a media for da'wah. Through Instagram da'wah is shared by posting videos, so that the audience can see and hear the messages of da'wah conveyed through videos or photos shared on Instagram ${ }^{6}$. Da'wah itself is aninvitation or exclamation, call or invitation to invite someone or a group of people. Da'wah through Instagram makes it easier for the public to get da'wah messages, because Instagram is a medium that has many users from various circles of society.

Instagram, as one of the most popular social media platforms among Indonesian youth in creating and expanding alternative spaces to build their identity as virtuous Muslims. Leveraging Instagram technology with its visual language Muslimah have created a forum wherethey invite and motivate others to become proper Muslims by engaging in $\mathrm{Hijrah}^{7}$

\footnotetext{
${ }^{5}$ Aziz Ali, IlmuDakwah. Cet III: Jakarta, Kencana Prenada media group, 2012 P.404

${ }^{6}$ Zulkifli M. (2005). Ilmu Dakwah. Makassar: Pustaka Al-Zikra. hlm. 2

${ }^{7}$ Nisa, Eva F. (2018). Creative and Lucrative. Da'wa: The Visual Culture of Instagram amongst Female Muslim Youth in Indonesia. Religious Studies, Victoria University of Wellington, hlm. 68-99
} 


\section{Religious Behavior}

According to Jalaluddin religious behavior is human behavior in relation to the influenceof belief on the religion he embraces. The meaning of religious behavior can be interpreted in a word, the word behavior means individual responses or reactions to stimuli or the environment; while the word religious comes from the word religion which means systems, principles, belief inGod with devotional teachings and obligations related to that belief. The word religious has got the prefix "to" and the suffix "an" which means anything (all actions) related to religion. Thus, religious behavior means all actions or deeds and words that a person does because of belief in $\operatorname{god}^{8}$.

Religious behavior is a person's real response or reaction as a result of accumulated experiences, experiences as a response he receives, which is manifested in daily forms of worshipsuch as: prayer, fasting, patience, tawakal, and hanging out with others ${ }^{9}$.

Measurement of religious behavior or religiosity can be seen from the three dimensionsof religious involvement: involvement of the mind (spiritual), physical involvement (body), and financial involvement (property). The more often a person involves himself in religious life, the higher the level of one's religiosity will be. On the other hand, someone who has never been involved in worship activities, both ritual and non-ritual, will mean a low level of religiosity. According to Paloutzian, the influence of religion can be positive or negative, on one's personal life and on the level of social life ${ }^{10}$.

To measure something that shows religious behavior or not can be seen from the characteristics of religious behavior. There are several things that can be used as indicators of a person's religious behavior ${ }^{11}$ :

1. Committed to Allah's commandments and prohibitions.

2. Eager to study religious teachings

3. Active in religious activities

4. Respect religious symbols

5. Familiar with the scriptures

\footnotetext{
${ }^{8}$ Jalaluddin, Psikologi Agama (Jakarta: PT Raja Grafindo Persada, 1997), 206

${ }^{9}$ Muhammad Alim, Pendidikan Agama Islam (Bandung: Remaja Rosdakarya, 2006), hlm.124

${ }^{10}$ Paloutzian, Invitation to the Psychology of Religion, (Massachusetts: A simon and Schuters, 2004), hlm 20

${ }^{11}$ Muhammad Alim, Pendidikan Agama Islam, (Bandung: PT Remaja Rosdakarya, 2011),hlm 12
} 
6. Using a religious approach in making choices

7. Religious teachings serve as a source of idea development

\section{Methods of Research}

This study conducted data analysis techniques by testing:

1. Validity test, aims to measure whether or not an item is valid. To determine whether the statement item is valid or not, a benchmark value is used in the Corrected item column Total Correlation. If the correlation number is above 0.2 , it is stated that the statement item is valid ${ }^{12}$.

2. Reliability test, according to Singarimbun and Effendi to measure the extent to which a measuring instrument can be trusted and reliable. This study used Cronbach's alpha technique.A questionnaire can be said to be reliable if the reliability coefficient is $>0.6^{13}$.

3. Normality test, which aims to test whether in the regression model, confounding variables orresiduals are normally distributed or not (Normality test can be detected in several ways, oneof which is using the One Sample Kolmogorov-Smirnov test. If the Asymp value is $\operatorname{Sig}(2)$ - tailed) $\geq 0.05$, then the data is normally distributed. Conversely, if the Asymp.Sig (2-tailed) value $<0.05$, the data is not normally distributed.

4. Correlation coefficient aims to measure the strength and show the direction of the relationshipbetween the dependent variable and the independent variable. The results of this test lie between the correlation value 0 to with 1 . If the resulting value is close to 0 , then there is no relationship between $\mathrm{X}$ and $\mathrm{Y}$ variables. If it gets closer to number 1, then the relationship between $\mathrm{X}$ and $\mathrm{Y}$ variables has a perfect relationship.

5. T test, to show how far the influence of variable $\mathrm{X}$ can explain the variation of variable $\mathrm{Y}$. Thecriteria, if the value is Sig. $\geq 0.05$, then Ha is not accepted, so there is no influence of variableX on variable Y. Conversely, if the value is Sig. $<0.05$, then Ha is accepted, so that there is aneffect of the independent variable on the dependent variable.

\footnotetext{
${ }^{12}$ Nisfianoor, Muhammad. (2013). Pendekatan Sistemarika Modern: Aplikasi Dengan Software SPSS dan Eviews. Jakarta: Penerbit Universitas Trisakti P.298

${ }^{13}$ Siregar, Syofian. (2013). Metode Penelitian Kuantitatif. Jakarta: PT FajarIntterpratama Mandiri P.57
} 
This research uses correlational quantitative methods. Population is a generalization areathat consists of objects / subjects that have certain qualities and characteristics determined by researchers to be studied and then drawn conclusions ${ }^{14}$. Based on this information, the populationin this study were students of the North Sumatra State Islamic University who had formally studied media related science. The Department of Communication and Broadcasting is one of thedepartments that studies media. The number of samples in this study was 76 students. The sampling technique is purposive sampling, according to Sugiyono that: "purposive sampling is atechnique for sampling data sources with certain considerations. Determination of the sample in this study using non-probability sampling is sampling that does not provide equal opportunities for representing the population to be selected as research samples, or non-random sampling. Thisstudy uses a Likert scale as a measurement scale statement of student perceptions. According to Sugiyono, the Likert scale is used to measure the attitudes, opinions and perceptions of a personor group of people about social phenomena.

\section{Finding}

frequency of accessing da'wah accounts

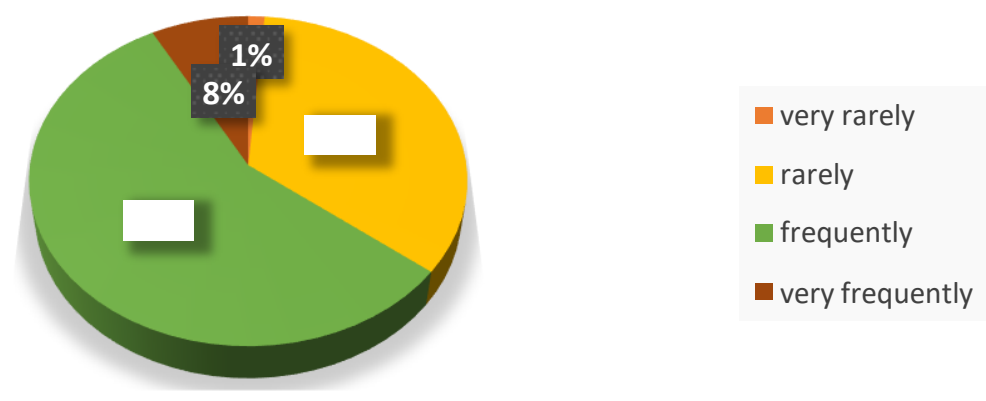

Based on the data in the diagram above, it shows that most of the respondents, namely $57 \%$, stated that they often access da'wah accounts. However, 34 percent stated that they rarely access da'wah accounts when they access Instagram.

\footnotetext{
${ }^{14}$ Sugiyono, (2016), Metode Penelitian Kuantitatif Kualitatif dan $R \& D$, alfabeta, Jakarta.
} 
Number of dakwah accounts that were followed

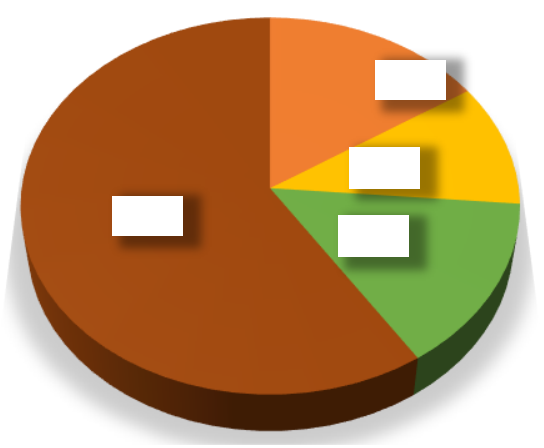

$$
\begin{aligned}
& 1 \text { account } \\
& 2 \text { account } \\
& -3 \text { account } \\
& -4 \text { account or more }
\end{aligned}
$$

Most of the respondents, namely 59\%, follow four or more da'wah accounts. The rest have a percentage that averages between one and three da'wah accounts. This shows the high student interest in da'wah accounts.

\section{Validity Test}

Table. 1. Validity X (Instagram)

\begin{tabular}{lllllll}
\hline & & $\mathrm{X}_{1}$ & $\mathrm{X}_{2}$ & $\mathrm{X}_{3}$ & $\mathrm{X}_{4}$ & $\mathrm{X}_{\text {total }}$ \\
\hline $\mathrm{X}_{\text {total }}$ & Pearson Correlation & $.697^{* *}$ & $.738^{* *}$ & $.716^{* *}$ & $.710^{* *}$ & 1 \\
& Sig. (2-tailed) & .000 & .000 & .000 & .000 & \\
$\mathrm{~N}$ & 76 & 76 & 76 & 76 & 76 \\
\hline
\end{tabular}

Source: Data Primer

Table. 2. Validity Y (Religious Behavior)

\begin{tabular}{llllllll|l|l|l|l|l}
\hline & & $\mathrm{Y}_{1}$ & $\mathrm{Y}_{2}$ & $\mathrm{Y}_{3}$ & $\mathrm{Y}_{4}$ & $\mathrm{Y}_{5}$ & $\mathrm{Y}_{6}$ & $\mathrm{Y}_{7}$ & $\mathrm{Y}_{8}$ & $\mathrm{Y}_{9}$ & $\mathrm{Y}_{\text {total }}$ \\
\hline $\mathrm{Y}_{\text {total }}$ & $\begin{array}{l}\text { Pearson } \\
\text { Correlation }\end{array}$ & $.718^{* *}$ & $.669^{* * *}$ & $.651^{* *}$ & $.771^{* *}$ & $.738^{* *}$ & $.735^{* *}$ & $.678^{* *}$ & $.673^{* *}$ & $.684^{* *}$ & 1 \\
& & & & & & & & & & \\
& Sig. (2-tailed) & .000 & .000 & .000 & .000 & .000 & .000 & .000 & .000 & .000 & \\
& $\mathrm{~N}$ & 76 & 76 & 76 & 76 & 76 & 76 & 76 & 76 & 76 & 76 \\
\hline
\end{tabular}

Source: Data Primer

The results of the observations on the r-Table show that the value of the sample $(\mathrm{N})$ is 76 respondents of 0.2257 . Referring to the results of the Validity Test, it is produced that all instruments starting from the $\mathrm{X}$ variable consisting of $\mathrm{X}_{1}, \mathrm{X}_{2}, \mathrm{X}_{3}, \mathrm{X}_{4}$, and $\mathrm{X}_{\text {total }}$, all result in the value of r-Count > r-Table. In addition, the variables of Religious Behavior (Y) which consist of $\mathrm{Y}_{1}, \mathrm{Y}_{2}, \mathrm{Y}_{3}, \mathrm{Y}_{4}, \mathrm{Y}_{5}, \mathrm{Y}_{6}, \mathrm{Y}_{7}, \mathrm{Y}_{8}, \mathrm{Y}_{9}$ and $\mathrm{Y}_{\text {total }}$ are all also yields the value $\mathrm{r}-\mathrm{Count}>\mathrm{r}-$ Table. It canbe concluded that all the instruments in this study are "valid". 


\section{Reliability Test}

Table. 3. Reliability X (Instagram)

\begin{tabular}{cc}
\hline Cronbach's Alpha & N of Items \\
\hline .648 & 4 \\
\hline
\end{tabular}

Source: Data Primer

Table. 4. Reliability Y (Religious Behavior)

\begin{tabular}{cc}
\hline Cronbach's Alpha & N of Items \\
\hline .870 & 9
\end{tabular}

Source: Data Primer

From the results of the reliability test, it was found that all the values of the $\mathrm{x}$ and $\mathrm{y}$ results resulted in a Cronbach alpha value > 0.6. It can be concluded that all the instruments in this studyare reliable.

\section{Normality Test}

Table. 5. Normality test on respondents' Instagram activities on religious behavior.

\begin{tabular}{|c|c|c|c|}
\hline \multicolumn{3}{|c|}{ One-Sample Kolmogorov-Smirnov Test } & \multirow{2}{*}{$\begin{array}{l}\text { Unstandardized Residual } \\
76\end{array}$} \\
\hline $\mathrm{N}$ & & & \\
\hline \multirow[t]{2}{*}{ Normal Parametersa,b } & Mean & & .0000000 \\
\hline & Std. Deviation & & 3.92298815 \\
\hline \multirow[t]{3}{*}{ Most Extreme Differences } & Absolute & & .100 \\
\hline & Positive & & 086 \\
\hline & Negative & & -.100 \\
\hline Test Statistic & & & .100 \\
\hline Asymp. Sig. (2-tailed) ${ }^{\mathrm{c}}$ & & & .055 \\
\hline \multirow[t]{3}{*}{ Monte Carlo Sig. (2-tailed) ${ }^{\mathrm{d}}$} & Sig. & & .057 \\
\hline & 99\% Confidence Interval & Lower Bound & .051 \\
\hline & & Upper Bound & .063 \\
\hline
\end{tabular}

Source: Data Primer

The normality test formula used in this study is the Kolmogorov-Smirnov Test. From the results of the normality test, the significance value of the test is $0.055>0.05$, it can be concludedthat the residual / population value is normally distributed. 


\section{Correlation Coefficient}

Table. 6. Model correlation coefficient (R) Respondent's Instagram Activity Variables (X)

\begin{tabular}{cccccc}
\hline Model & $\mathrm{R}$ & R Square & Adjusted R Square & Std. Error of the Estimate & Sig. F Change \\
\hline 1 & $.063^{\mathrm{a}}$ & .004 & -.010 & 3.94941 & .591
\end{tabular}

Somber: Data Primer

From the table. 6. Above it is concluded that the correlation coefficient (R) for the independent variable of Instagram user activity $(\mathrm{X})$ is 0.063 . This means that the relationship between $\mathrm{X}$ and $\mathrm{Y}$ is in the Person Correlation value 0.00 to 0.20 which means that it has no correlation at all.

Based on the table. 6. also obtained the coefficient of determination (R2) of 0.004. It meansthat the ability of the independent variable to influence the activity of Instagram users (X) on religious behavior is $0.4 \%$, while the rest is $99.6 \%$ influenced by factors outside variable $\mathrm{X}$ whichare not explained in the regression model of this study.

Table. 7. Correlation coefficient (R) Respondent's Instagram Activity Variables (X)

\begin{tabular}{|c|c|c|c|c|c|c|}
\hline & \multirow{2}{*}{ Model } & \multicolumn{2}{|c|}{ Unstandardized Coefficients } & $\begin{array}{l}\text { Standardized } \\
\text { Coefficients }\end{array}$ & \multirow[t]{2}{*}{$\mathrm{T}$} & \multirow[t]{2}{*}{ Sig. } \\
\hline & & B & Std. Error & Beta & & \\
\hline \multirow[t]{2}{*}{1} & (Constant) & 26.651 & 1.945 & & 13.702 & .000 \\
\hline & Instagram & .086 & .159 & .063 & .539 & .591 \\
\hline
\end{tabular}

Source: Data Primer

Table Data. 7. Above, it is known that the value of Constant (a) is 26.651 which means thatthe value of religious behavior is 26.651 . The $\mathrm{X}$ regression coefficient of 0.086 states that every $1 \%$ addition of the Respondent's Instagram Activity value, the value of religious behavior increases by 0.086 . The regression coefficient is positive, so it can be said that the direction of the influence of variable $\mathrm{X}$ on $\mathrm{Y}$ is positive.

Based on the significance value, it is obtained a significance value of 0.591>0.05, so it canbe concluded that the Respondent's Instagram Activity variable (X) has no significant effect on the religious behavior variable $(\mathrm{Y})$. based on the $\mathrm{t}$-count value of $0.539<0.05$, so it can be concluded that the Respondent's Instagram Activity variable (X) has no significant effect on the religious behavior variable (Y). 


\section{Conclusion}

Students have an interest in Instagram which contains da'wah content, this is evidenced by their activities on Instagram. They become followers of da'wah accounts and there are even some respondents who have more than 4 da'wah accounts. In addition, some of the respondents also stated that they often access these da'wah accounts. However, based on the research and analysis conducted by researchers regarding the influence of Da'wah on Instagram on the Religious Behavior of Islamic Communication and Broadcasting Students (KPI) at the State Islamic University of North Sumatra. It is concluded that the results of statistical processing assisted by the SPSS for Windows 16 program show that Instagram da'wah accounts do not havea significant effect on the religious behavior on students of Islamic Communication and Broadcasting (KPI).

\section{REFERENCE:}

Abdullah. 2007. E-Dakwah: Berdakwah Melalui Internet. Al-Hikmah. Jurnal Ilmu Dakwah Dan Pengembangan Masyarakat, Edisi 02..

Aditya R. 2015. Pengaruh Media Sosial Instagram Terhadap Minat Fotografi Pada Komunitas Fotografi Pekanbaru. Jom FISIP Volume 2 No. 2.

Ali A. 2012. Ilmu Dakwah. Jakarta: Kencana Prenada. Media Group. Cetakan ke III.Alim M. 2006. Pendidikan Agama Islam. Bandung: Remaja Rosdakarya. Jalaluddin. 1997. Psikologi Agama. Jakarta: PT Raja Grafindo Persada.

Lup K., Trub L., and Rosenthal L. 2015. Instagram \#Instasad?: Exploring Associations Among Instagram Use, Depressive Symptoms, Negative Social Comparison, and Strangers Followed. Cyberpsychology, Behavior, And Social Networking. Mary Ann Liebert, Inc. Volume 18, Number 5, 2015.

Muchtar N., and Ritchey J A. 2014. Preaching, Community, and Convergence: Use of Old and New Media by Profressive Indonesian Islamic Leaders. The International Communication Gazette.

Nisa, E F. 2018. Creative and Lucrative Dawa: The Visual Culture of Instagram amongst Female Muslim Youth in Indonesia. Religious Studies, Victoria University of Wellington.

Nisfianoor M. 2013. Pendekatan Sistemarika Modern: Aplikasi Dengan Software SPSS 
danEviews. Jakarta: Penerbit Universitas Trisakti.

Paloutzian. 2004. Invitation to the Psychology of Religion. Massachusetts: A simon andSchuters.

Siregar S. 2013. Metode Penelitian Kuantitatif. Jakarta : PT Fajar Interpratama Mandiri.

Sugiyono. 2016. Metode Penelitian Kuantitatif Kualitatif dan Research and

Development.

Alfabeta. Jakarta.

Zulkifli M. 2005. Ilmu Dakwah. Makassar: Pustaka Al-Zikra. 